ISSN 1392-1541

Geodezija ir kartografija, 2005, XXXI t., Nr. 2 Geodesy and Cartography, 2005, Vol XXXI, No 2

UDK 528.92

\title{
TOPOLOGINIO 3D MODELIO KŪRIMO GEOINFORMACINĖSE SISTEMOSE YPATUMAI
}

\author{
Kęstutis Čypas \\ Geodezijos ir kadastro katedra, Vilniaus Gedimino technikos universitetas, \\ Saulètekio al. 11, LT-10223 Vilnius-40,Lietuva, el.paštas: Kestutis.Cypas@ap.vtu.lt \\ Iteikta 200406 06, priimta 20050314
}

\begin{abstract}
Santrauka. Sudarant 3D topologinį modeli geoinformacinių sistemų erdvèje iškyla topologinių ryšių tarp objektu trimateje erdveje nustatymo problema. Straipsnyje pateikiamos topologinio 3D modelio kūrimo problemos ir nagrinejjamas teorinis topologinių ryšiu nustatymo būdas. Ryšiams nustatyti panaudotas objektiškai orientuotas modelis, pagrisstas simpleksais bei grafų teorija. Galimos topologinès sąsajos trimatėje erdveje nustatytos taikant devynių susikirtimų modelį. Gautų sąsajų tarp objektų trimateje erdvejje skaičius skiriasi nuo kitų autorių gautų rezultatų, todèl galima patvirtinti, kad jis priklauso nuo pasirinkto modelio, topologinių sąsajų nustatymo būdo bei kitų išankstinių sąlygų.
\end{abstract}

Raktažodžiai. 3D GIS modelis, topologinès sąsajos 3D erdvèje.

\section{Ivadas}

Skaitmeninio 3D GIS modelio poreikis bei realizavimo būdai aptariami įvairiose konferencijose, seminaruose, straipsniuose. Tobulejant technologijoms bei intensyvejjant ekonominiam augimui informaciniu technologijų ir telekomunikacijų srityje didèja sprendimu, pagristu informaciniu technologiju taikymu, poreikis, taigi daugejja 3D GIS modelių taikymo sričių. Šiandien tai - miestų urbanistinis projektavimas, nekilnojamojo turto kadastras, telekomunikaciju tinklo modeliavimas, gelbejjimo tarnybu operacijų planavimas, aplinkos monitoringas, triukšmo lygio prognozavimas, potvynių prognozavimas, taršos modeliavimas; geologinis modeliavimas ir kt [1]. Šiame straipsnyje aptariami topologinio 3D GIS modelio teoriniai kūrimo ypatumai ir problemos. Jo poreikis ypač svarbus nekilnojamojo turto kadastre, ten, kur svarbios sąsajos tarp objektu ne tik plokštumoje, bet ir vertikalioje erdveje. Be abejo, 3D GIS modelius taikyti tik vienoje srityje tampa labai brangu, todèl tik jungiant taikymo sritis galima sumažinti tokio topologinio 3D modelio parengimo bei kūrimo sąnaudas. Taikymo sričiu mastas priklauso nuo to, kiek toks modelis gali būti naudingas kitoms sritims. Komercinių programų gamintojai laukia mokslininkų, siūlančių i̇diegimo technologijas, rezultatų, todèl ši sritis tampa labai aktuali.

Jau iprasta, kad GIS duomenys saugomi centrinèse reliacinèse duomenų bazèse $(R D B V S)$, kurios gali veikti ir paskirstytujų duomenų bazių režimu, t. y. kai skirtingų nuosavybiu duomenys saugomi skirtingose GIS duomenu tarnybinèse stotyse [2], taigi ir 3D GIS modelis privalo remtis centriniu paskirstytuju duomenu baziu principais. Kol kas nèra komercinių 3D GIS topologinio modelio sprendimų, viena iš priežasčių - OGC (Open GIS Consortium) parengta specifikacija kol kas neapima 3D objektų. Šiuo metu tokia specifikacija yra rengiama, tačiau ji labai priklauso nuo suinteresuotujuc sričiu poreikio bei mokslinių tyrimų rezultatų, kuriais remiantis galima būtų efektyviai įdiegti 3D GIS modeli. Nepaisant to, 3D GIS technologijos sparčiai tobuleja, tačiau neesant vieningos specifikacijos (reikalavimu) iš esmès susiduriama su šiais sunkumais: 3D GIS objektu konstravimas (kūrimas, redagavimas), manipuliavimas ir analizè (užklausos, sankirta, buferių generavimas, trumpiausio kelio radimas), 3D GIS duomenu organizavimas [3].

Erdvinė analizė dažnai laikoma vienu iš svarbiausių geoinformacinių sistemų uždavinių. 3D GIS analizé tebėra iki galo neišspręstas uždavinys, ir mokslininkai intensyviai tebedirba. Gali būti skiriami du aspektai: kaip objektai ir jų erdviniai ryšiai turètų būti reprezentuojami bei kokia technika naudojama tiems ryšiams atpažinti.

Straipsnyje analizuojamas grafu taikymas objektams aprašyti 3D erdvėje. Nagrinėjamas topologinis 3D GIS modelis remiasi objektiškai orientuoto modelio struktūra, rekomenduojama literatūroje [4]. Toliau nagrinejjamos ir galimos sąsajos tarp objektu $R^{3}$ erdvejje lyginant su anksčiau nustatytomis sąsajomis.

\section{3D topologinio modelio taikymas urbanizuotose teritorijose}

Urbanizuotose teritorijose, kur intensyvus žemès naudojimas, tankus užstatymas, bręsta poreikis 3D GIS modeli taikyti kadastruose. Kyla būtinybè šiose teritorijose išnaudoti erdvę, esančią po žeme ar virš žemès, bei tokias valdas registruoti juridiškai. Pirmieji 


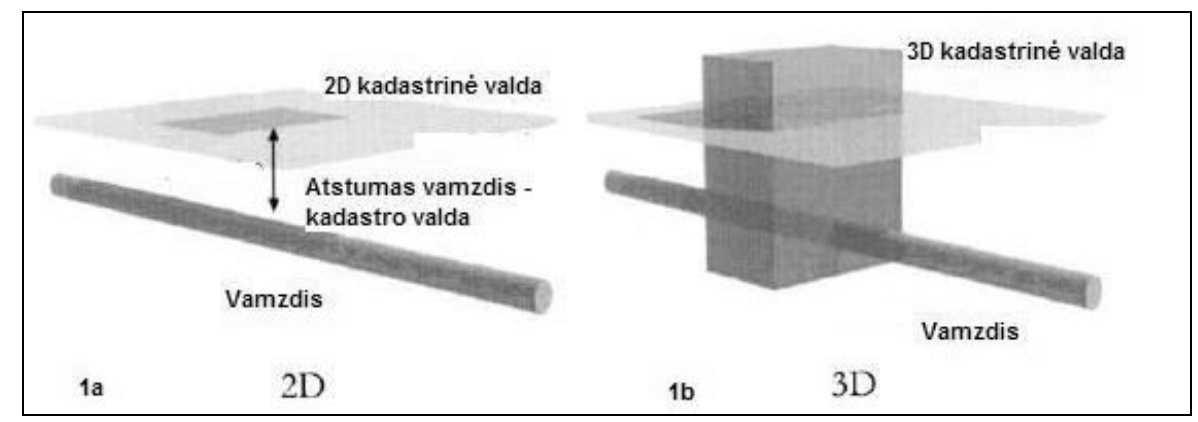

1 pav. Kadastro valda ir po ja einantis vamzdis dalinio 3D modelio atveju ir pilnutinio 3D modelio atveju Fig 1. Cadastre domain and pipe below with partial 3D model case and full 3D model case

analizavimo etapai parode, kad toks poreikis tikrai yra, tačiau daug neaiškumų dèl tokio valdos objekto apibrěžimo esti ir juridinèje, ir GIS plotmèse [5]. Kita iš problemų - didelès tokios sistemos sukūrimo ir palaikymo sąnaudos. Kadastrų informacinèse sistemose naudojami ir skaitmeniniai žemėlapiai, savo ruožtu sudaromi ir naudojami kitų atsakingujų institucijų, kuriančių skirtingos tematikos skaitmeninius žemèlapius, todèl siūloma duomenis kurti bendrai. Miestų savivaldybès, atsakingos už miesto stambiojo mastelio kartografinès medžiagos patikimumą ir naujumą bei kuriančios miestų plètros strateginius planus, taip pat supranta poreiki tokią informaciją kaupti ir panaudoti. Inžinerinių komunikacijų imonėms tokios informacijos saugojimas leistu daug kokybiškiau ir efektyviau projektuoti rekonstrukcijas, statybas ne tik joms pačioms, bet ir kitoms imonèms, toje teritorijoje atliekančioms statybos ar rekonstravimo darbus.

Viena iš užklausų, pasitaikančių atliekant teritorinị miesto projektavimą - rasti savininkus, susijusius su objektu ar reiškiniu, paplitusiu geografiniu požiūriu (inžinerinès komunikacijos, jų projektas, kelio projektas, taršos paplitimas, kt.). Tokiu atveju daroma reiškinio ar objekto sankirta 2D erdvejje su kadastrine valda ir nustatoma, ar yra bendrų dalių. Iš tikrujų tai užklausa, kuri remiasi sąsajų tarp objektų savybėmis, t. y. tai topologinè užklausa. Kaip tokia užklausa galètų būti realizuojama naudojant 3D modelį? Iš esmès klausimas tuomet būtų panašus: ,,ar objektai susikerta erdveje, t. y. ar turi bendrų dalių?" Jei objektai kertasi 2D erdvejje, jie nebūtinai kirsis 3D erdvèje. Nagrinèjant šị klausimą galima būtų nusibrèžti tokias sąlygas:

1) dalinis 3D modelis - kadastro objektas (valda) lieka 2D erdvejje, objektas, su kuriuo valda sukertama, turi 3D savybes (1 pav. a);

2) pilnutinis $3 \mathrm{D}$ modelis - ir kadastro objektas, t. y. valda, ir objektas turi 3D savybes (1 pav. b) [6].

Pirmuoju atveju būtų būtina:

a) „susieti“ objektus įvedant atstumą iki kadastrinès valdos kaip požeminès komunikacijos objekto atributą (paprastai inžinerinès komunikacijos igilinimas yra žinomas tik atraminiuose taškuose);

b) apskaičiuoti atstumą tarp objektų.

Antruoju atveju, kai abu objektai turi 3D savybiu, atsakymas būtų daug svarbesnis. Šiuo atveju topologinis modelis leistų tiksliai atsakyti ị ši klausimą - inžinerinès komunikacijos kerta kadastro objektą tam tikroje vietoje, kuri apibūdinama koordinatėmis.

Erdvinès sankirtos, apibrěžus topologinius ryšius tarp 3D objektų, būtų įmanomos ir tarp tūrinių objektų bei 3D savybes turinčių reiškinių, pvz.: pastatu ir kadastriniu valdų, pastatu ir taršos (taip pat triukšmo), telekomunikacijų bangų sklidimo.

Imanomas būdas - erdvę skaidyti, pvz.: kadastro valdomis, jam realizuoti būtina žinoti ir erdvines sąsajas tarp 3D objektu (2 pav.) [6].

\section{Objektų aprašymas grafais 3D erdvèje}

Topologijos taikymas sąsajoms tarp objektų apibrèžti leidžia išsaugoti šias sąsajas atliekant įvairias transformacijas, tokias kaip vertimas, sukimas, didinimas. Daugelis realaus pasaulio 2D modeliu, kurie užtikrina topologiją, pagristi grafų teorija. Planinejje erdvejje grafas reprezentuojamas briaunomis ir viršūnemis, esant briaunuc susikirtimams, papildomai ir mazgais. Tinklo bei poligonu analizè taip pat atliekama taikant grafus: bet kokiam orientuotajam grafui yra tik vienas poligonas iš dešinès ir tik vienas poligonas iš kairès ( 3 pav.). Pvz., poligono briaunoms rasti taikomas algoritmas NAF (next oriented arc with the same face), kuris randa kita orientuotaji grafą, priklausanti tam pačiam poligonui ir esančiam iš kairès (3 pav.), o algoritmas NAN (next oriented arc with the same end node) gauna kitą orientuotaji grafą su tuo pačiu mazgu (3 pav.).

Toks modelis, deja, negali būti taikomas 3D erdveje tiesiogiai. Taikant ši modeli kyla problemų, nes ta pati briauna 3D modelyje gali priklausyti daugiau nei dviems poligonams. Tačiau tokio modelio orientuotaji grafa išskaidžius i du skirtingus objektus - i orientuotaji poligoną (arba kitaip - paviršių, plokštuma) ir i porą plokštumą su orientuotuoju grafu (žymima: plokštuma, orientuotasis grafas), galima šią problemą išspręsti [4]. Palyginiti su 2D objektais, orientuotasis grafas atitiktu pora - briauną su kryptimi ir pabaigos mazgu. Vis delto nors ir yra atitikmuo tarp orientuotojo grafo ir poros briaunos su kryptimi ir pabaigos mazgu 2D erdvejje, realiai nèra atitikmens 3D erdvejje tarp orientuotosios plokštumos ir poros (plokštuma, orientuotasis grafas), nes orientuotoji plokštuma gali nurodyti kelias poras (plokštuma, orientuotasis grafas), kadangi plokštumos ribą gali sudaryti keli orientuotieji grafai. Atitikmenys pateikti 1 lentelèje. 


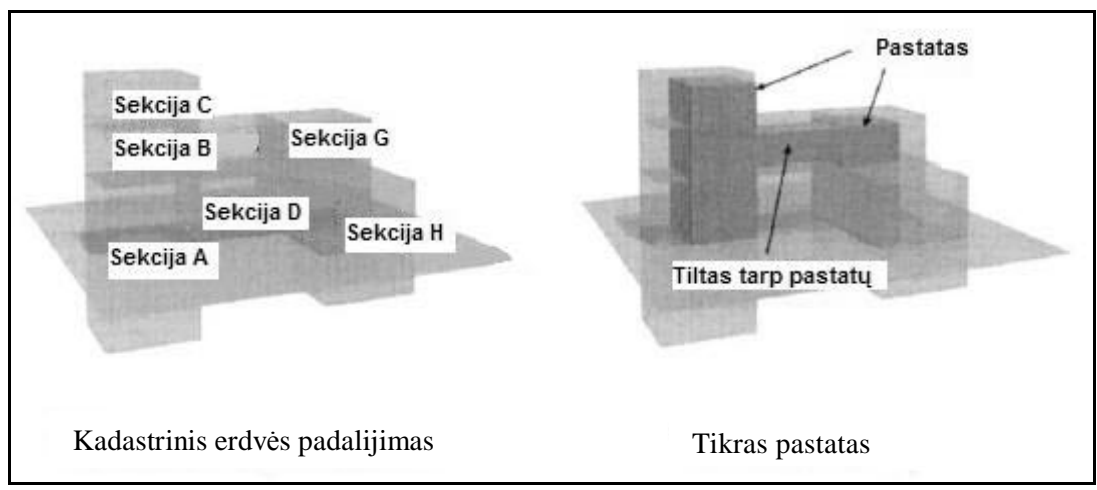

2 pav. Kadastrinis erdvès padalijimas

Fig 2. Cadastral space partition

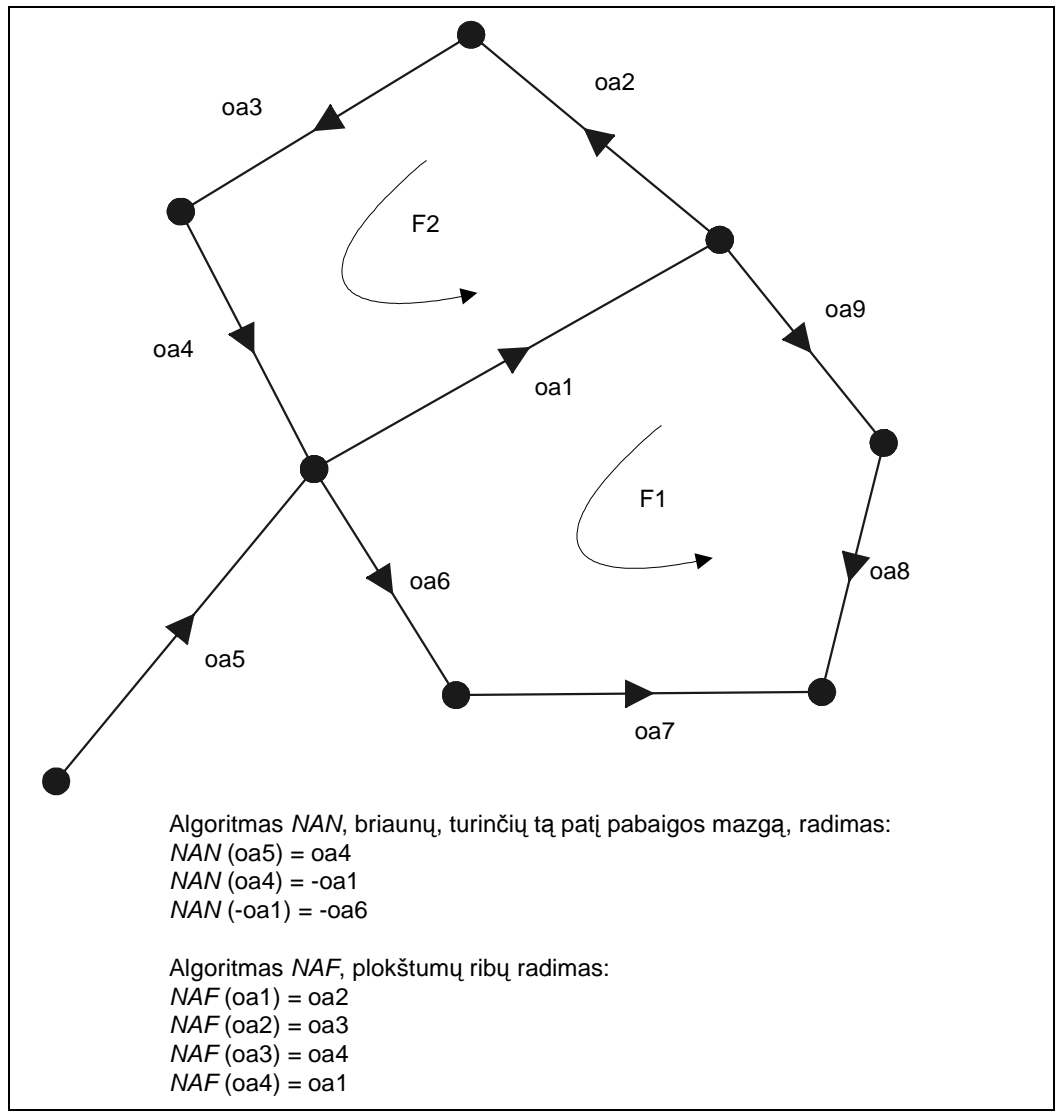

3 pav. Topologijos algoritmu pavyzdys $2 \mathrm{D}$

Fig 3. Example of topological algorithms in 2D

1 lentelè. Atitikmenys 2D ir 3D erdvèse

Table 1. Equivalences between $2 \mathrm{D}$ and $3 \mathrm{D}$ spaces

\begin{tabular}{|l|l|}
\hline 2D topologinis modelis & 3D topologinis modelis \\
\hline Briauna & Paviršius arba plokštuma (face) \\
\hline Poligonas dešinėje & Tūris (volume) dešinėje \\
\hline Orientuotasis grafas & Orientuotasis paviršius \\
\hline Orientuotasis grafas & Plokštuma, orientuotasis grafas \\
\hline$I N V$ & $N C F$ \\
\hline$N A N$ & $N C A$ \\
\hline$I N V$ & $I N V$ \\
\hline$N A F$ & $N C A{ }^{\circ} I N V$ \\
\hline Poligonas $($ face $)$ & Tūris (volume) \\
\hline Skylė (hole $)$ & Kiaurymè, tuščia ertmè, erdvė (cavity) \\
\hline
\end{tabular}


Ryšiai tarp 3D objektų porų išvesti remiantis ryšiais 2D erdvejje. Taigi keičiami šie algoritmai: INV (kita pora toje pačioje briaunoje (inversija), next couple with the same edge) i $N C F$ (kita pora toje pačioje plokštumoje, next couple with the same face), NAN (kitas orientuotasis grafas su tuo pačiu pabaigos mazgu, next oriented arc with the same end node) i NCA (kita pora tame pačiame orientuotame grafe, next couple with the same oriented $\operatorname{arc}$ ) ir INV (inversijos pora). Toks ryšiu aprašymas leistu nustatyti plokštumos ribas (kontūrus) taikant algoritmą $N C F$, t. y. tik vieną porą (plokštumą, orientuotaji grafa), bei rasti visas plokštumas, turinčias vieną briauna, algoritmas NCA (4 pav.) - ir visus orientuotuosius grafus, kurie turi tą pati pabaigos mazgą, tūrio riboms nustatyti.

\section{Simpleksų taikymas 3D modeliuoti}

Topologiniams ryšiams užtikrinti geometriniu lyg- meniu gali būti taikomi simpleksai. Simpleksais aprašomi neorientuotieji objektai, nes orientuotieji objektai apibūdinami neorientuotaisiais objektais (5 pav.). Erdviniai objektai klasifikuojami pagal dimensiją, kiekvienai dimensijai egzistuoja minimalus objektas, vadinamas simpleksu [7]. Bet koks $n$-osios dimensijos simpleksas yra sudarytas iš $(n+1)$ geometriškai nepriklausomų (n-1) dimensijos simpleksų. Pavyzdžiui, trikampis yra 2-osios dimensijos simpleksas, sudarytas iš trijų 1-osios dimensijos simpleksu. Šie 1-osios dimensijos simpleksai yra geometriškai nepriklausomi, jei nèra dviejų lygiagrečių briaunų ir nėra briaunų, kurių ilgis lygus 0 [7]. Mažiausias erdvinis objektas yra 0 dimensijos simpleksas, kuris išreiškia mazgus, 1-osios dimensijos simpleksai išreiškia briaunas, 2-osios dimensijos simpleksai - trikampius, 3-osios dimensijos simpleksai išreiškia tetraedrus.

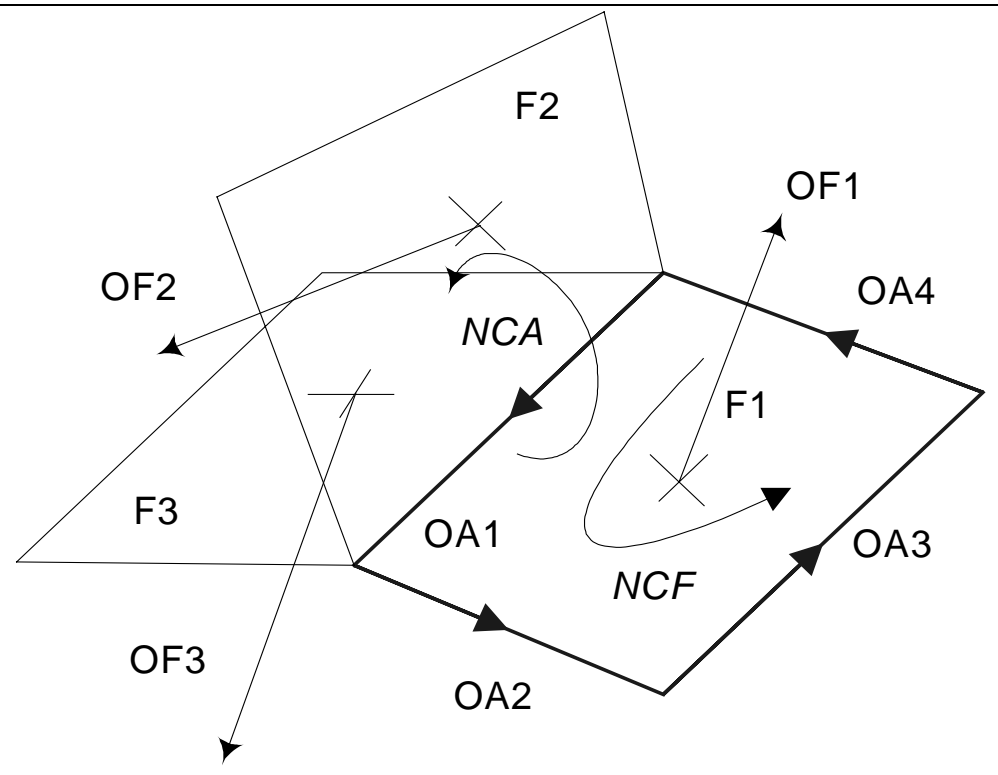

Algoritmas $N C F$, plokštumu ribų radimas:

$N C F((\mathrm{~F} 1, \mathrm{OA} 1))=(\mathrm{F} 1, \mathrm{OA} 2)$

$N C F((\mathrm{~F} 1, \mathrm{OA} 2))=(\mathrm{F} 1, \mathrm{OA} 3)$

$N C F((\mathrm{~F} 1, \mathrm{OA} 3))=(\mathrm{F} 1, \mathrm{OA} 4)$

$N C F((F 1, O A 4))=(F 1, O A 1)$

Algoritmas $N C A$, plokštumu, turinčiu tą pačią briauna, radimas:

$\operatorname{NCA}((\mathrm{F} 1, \mathrm{OA} 1))=(\mathrm{F} 2, \mathrm{OA} 1)$

$N C A((\mathrm{~F} 2, \mathrm{OA} 1))=(\mathrm{F} 3, \mathrm{OA} 1)$

$N C A((\mathrm{~F} 3, \mathrm{OA} 1))=(\mathrm{F} 1, \mathrm{OA} 1)$

4 pav. Topologijos algoritmu pavyzdys $3 \mathrm{D}$

Fig 4. Example of topological algorithms in $3 D$ 


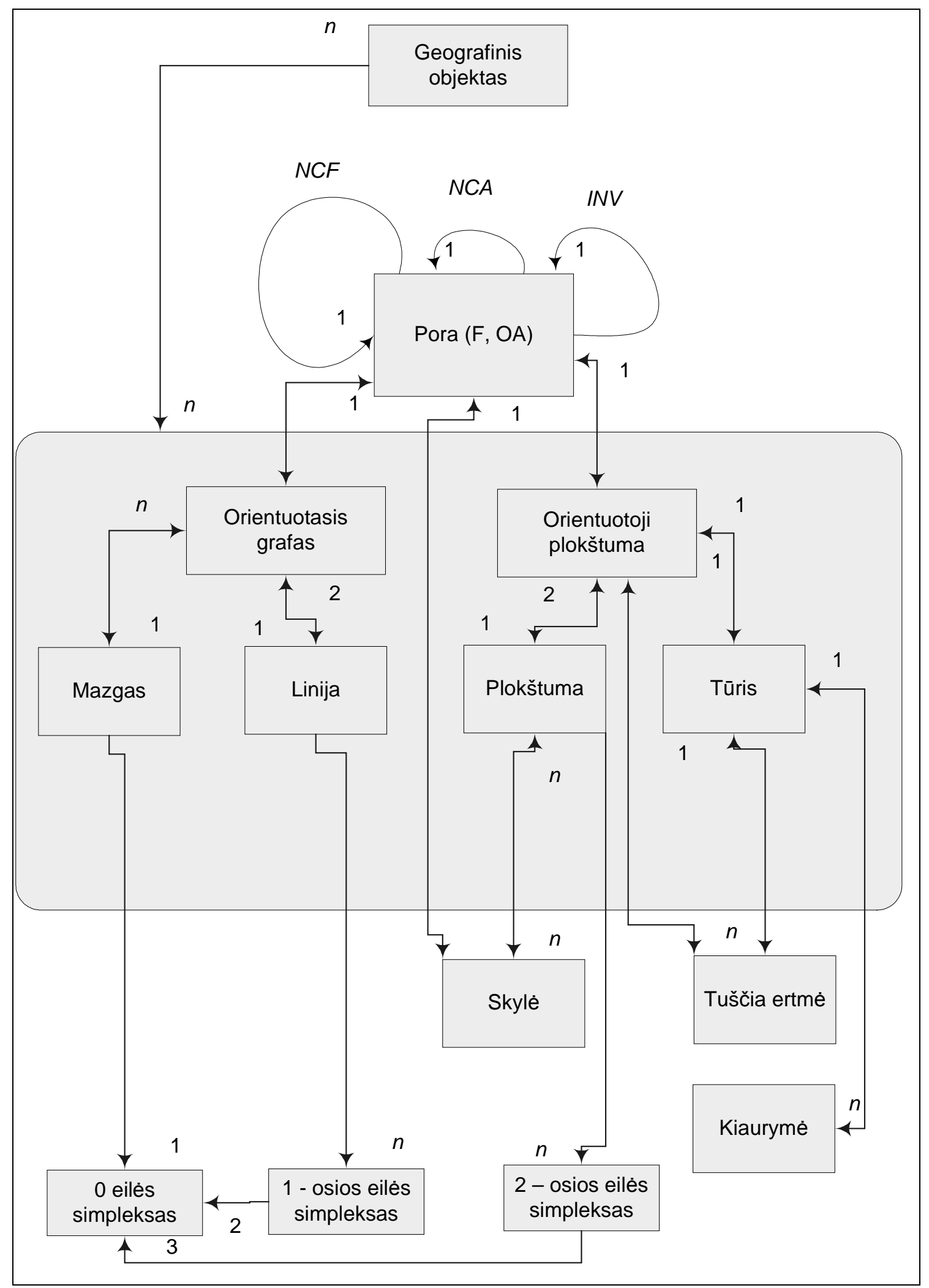

5 pav. 3D GIS modelis

Fig 5. 3D GIS model 
3D ryšiams aprašyti pakanka apsiriboti $k$-osios dimensijos simpleksu, kai $0 \leq k \leq 3$. Taigi tūriniai objektai susidès iš tetraedrų, toks suskaidymas leistu valdyti topologinius ryšius tarp objektų bei tarp kompleksinių plokštumų (su skylèmis ir kt.). Topologinis ryšys užtikrinamas tarp pačių objektu, tiesioginis simpleksų topologinis valdymas iš tikrujų nèra atliekamas, tai atimtų daug vietos saugojimo laikmenose bei laiko apdorojant užklausas. Kai yra skylių, kiaurymių bei tuščiu erdvių, plokštumų nebūtina dalyti i kelias dalis.

Skaidymas i simpleksus iš esmès tinka briaunoms ir plokštumoms (kaip ir 2D erdvejje, kur poligonus skaidyti $\mathfrak{i}$ trikampius nèra svarbu), tūrinių objektų skaidymas $\mathfrak{i}$ tetraedrus iš esmès atliekamas tūriams skaičiuoti, tačiau modelyje 3-osios dimensijos simpleksai nesaugomi.

\section{3D GIS topologinis modelis}

Siūlomas 3D GIS topologinis modelis, pristatytas de la A. Losa ir B. Cervelle [4], yra objektiškai orientuotas (5 pav.), tai realizuota saugant plokštumas ir susijusias jas apibūdinančias bendras briaunas modelyje. Taip užtikrinami topologiniai ryšiai. Modelyje saugomi orientuotieji grafai, susiję su mazgais ir linijomis, orientuotieji paviršiai, susiję su plokštumomis ir tūriais, bei poros (plokštuma, orientuotasis grafas). Toks modelis leidžia valdyti tuščias ertmes bei kiaurymes (6 pav.).

\section{Topologiniai ryšiai 3D erdvėje}

Topologiniams ryšiams apibūdinti 3D erdvėje taikomas 9 susikirtimu modelis (9 intersection model) [8]. Jis patvirtintas OpenGIS konsorciumo kaip diegti tinkama struktūra. Jo esmè - sankirtų tarp objektų A ir B apibūdinimas toje pačioje topologineje erdvejje $\Lambda$ taikant ribą (boundary, $\partial A, \partial B$ ), vartojant vidaus (interior, $A^{\circ}$, $B^{\circ}$ ) ir išorès (exterior, $A^{-}, B^{-}$) sąvokas. Tada binarinis ryšys $R(A, B)$ tarp objektu identifikuojamas komponuojant visas galimas sankirtas tarp 6 topologiniu primityvų [8]:

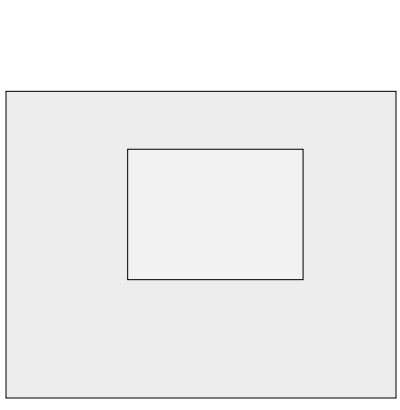

Skylè plokštumoje

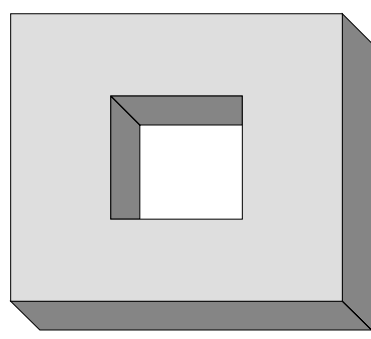

Kiaurymè

$$
R(A, B)=\left[\begin{array}{ccc}
\partial A \cap \partial B & \partial A \cap B^{\circ} & \partial A \cap B^{-1} \\
A^{\circ} \cap \partial B & A^{\circ} \cap B^{\circ} & A^{\circ} \cap B^{-1} \\
A^{-1} \cap \partial B & A^{-1} \cap B^{\circ} & A^{-1} \cap B^{-1}
\end{array}\right]
$$

Sankirtos rezultatas - tuščioji aibė ( $\varnothing)$ arba netuščioji aibè $(\neg \varnothing)$. Pvz., jei du objektai turi bendra ribą, sankirta tarp dviejų ribų yra netuščioji aibè, t. y. $\partial \mathrm{A} \cap \partial \mathrm{B}=\neg \varnothing$; jei yra susikertančių vidaus erdvių, tuomet sankirtos rezultatas yra netuščioji aibè, t. y. $\mathrm{A}^{\circ} \cap \mathrm{B}^{\circ}=\neg \varnothing$. Kadangi principas yra toks, kad kiekviena sankirtos pora gali būti tuščioji aibė arba netuščioji aibè, skirtingi modeliai aprašo skirtingus ryšius. Teoriškai ryšių sankirtu kombinacijų skaičius gali būti $2^{9}$, t. y. 512 , jei įtrauksime ir objektų dimensijas $(0,1,2,3 \mathrm{D}$, kur 0 - taškas, 1 linija, 2 - plokštuma, paviršius, 3 - tūris), tai kombinaciju skaičius padidès iki $512 \times 16=8192$, tačiau praktikoje bus naudojamas tik nedidelis kombinaciju skaičius. Skirtingu tyrimu šioje srityje rezultatai skirtingi (priklausomai nuo modelio), todèl kiekvienas atvejis turi būti nagrinejjamas atskirai.

Šio tyrimo metu buvo nagrinejami galimi ryšiai ir lyginami su gautais anksčiau. Taškai bus žymimi $P$, linijos $L$, plokštumos $S$, tūriai $B$. Pažymëjimas $R(L, S)$ reikštų binarini ryši tarp linijos ir plokštumos, kai linija imama kaip pirmasis objektas. Ryšys $R(S, L)$ yra atvirkščias ryšys, vadinamas atvirkštine sąlygos dalimi. Paprastumo dèlei tuščioji aibe žymima 0 , o netuščioji 1 . Tada ryšys tarp objektų su nesusikertančiomis ribomis ir vidaus erdvėmis žymimas 000011111, ši binarini (dvejetainị) kodą pavertę dešimtainiu gausime 31, žymima R031 (ryšys „nesusikerta“). Apibendrintieji tyrimo rezultatai pateikiami 2 lentelèje.

Rezultatai gauti pirmiausia atmetant neimanomus ryšius ir tuomet nagrinejjant kiekvieną sankirtą tarp objektų $P, L, S, B$ skirtingoje erdveje $I R, I R^{2}, I R^{3}$ [9]. Gauti ryšiai klasifikuojami: nesikerta (disjoint), turi savyje, apima (contains), yra viduje (inside), lygūs (equal), ribojasi (meet), dengia (covers), dengiamas (covered by), uždengtas (overlap).

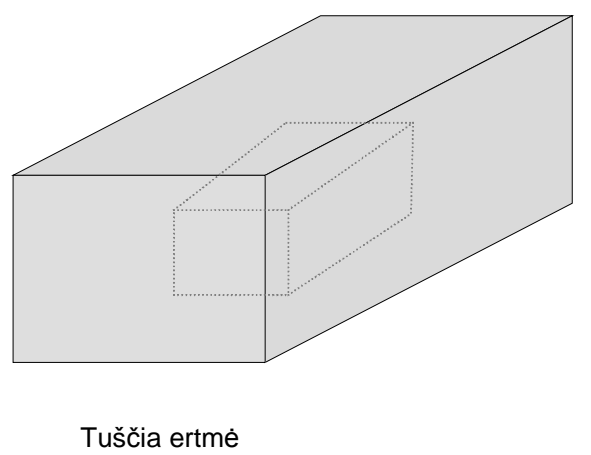

6 pav. Skylès, kiaurymès, tuščios ertmės pavyzdys

Fig 6. Examples of hole, opened hole, cavity 
2 lentelè. Ryšiai tarp objektų $I R, I R^{2}, I R^{3}$ erdvejje

Table 2. Relations between objects in $I R, I R^{2}, I R^{3}$ spaces

\begin{tabular}{|l|l|}
\hline \multicolumn{1}{|c|}{ Ryšiai $\boldsymbol{R}(\boldsymbol{X}, \boldsymbol{Y})$} & \multicolumn{1}{|c|}{$\begin{array}{c}\text { Ryšių } \\
\text { skaičius }\end{array}$} \\
\hline$B L, L B$ (tūris ir linija $I R^{3}$, body and line) & 19 \\
\hline$B S, S B$ (tūris ir plokštuma $I R^{3}$, body and surface) & 19 \\
\hline$B B$ (tūris ir tūris $I R^{3}$, body and body) & 8 \\
\hline$P B$ (taškas ir tūris $I R^{3}$, point and body) & 3 \\
\hline$S L, L S$ (plokštuma ir linija $I R^{2}, I R^{3}$, surface and line) & 31 \\
\hline$S S$ (plokštuma ir plokštuma $I R^{2}, I R^{3}$, surface and surface) & 38 \\
\hline$P S, S P$ (taškas ir plokštuma $I R^{2}, I R^{3}$, point and surface) & 3 \\
\hline$L L\left(\right.$ linija ir linija $I R, I R^{2}, I R^{3}$, line and line) & 33 \\
\hline$P L, L P$ (taškas ir linija $I R, I R^{2}, I R^{3}$, point and line) & 3 \\
\hline$P P$ (taškas ir taškas $I R, I R^{2}, I R^{3}$, point and point) & 2 \\
\hline \multicolumn{1}{|c|}{ Iš viso: } & 159 \\
\hline
\end{tabular}

\section{Išvados}

1. Nustatyti topologiniai ryšiai $3 \mathrm{D}$ erdveje tarp 0,1 , 2, 3 dimensijos objektų, taikant 9 sankirtu topologini modelị objektiškai orientuotam modeliui, pagristam grafų teorijos principais.

2. Nustatytų topologinių ryšiu skaičius skiriasi nuo kitų autorių gautų ryšių skaičiaus. Tai dar kartą ịodo, kad vieno bendro atsakymo nèra, o rezultatas priklauso nuo nagrinėjamo 3D GIS modelio bei nustatytujų sąlygų.

3. Topologinių ryšiu modelis gali būti diegiamas nustatant išankstines sąlygas, taisykles ir apribojimus. Kadangi topologinių ryšių skaičius gana didelis, visus įdiegti būtų sudètinga ir nebūtina, todèl reikètų pradèti nuo svarbiausiujuc, o konkretų ryši parinkti galètų vartotojas.

\section{Literatūra}

1. Čypas, K. Preparation of 3D digital city model development technology based on geoinformation systems. Geodezija ir kartografija (Geodesy and Cartography), Vol XXIX, No 3. Vilnius: Technika, 2003. 90-97 p.

2. Stankevičius, Ž. Investigation of city geographic information system optimality (Miesto geoinformacinès sistemos optimalumo tyrimas). $\mathrm{PhD}$ dissertation. Vilnius, 2000.

3. Stoter, J.; Zlatanova, S. 3D GIS, where are we standing? ISPRS Joint Workshop on „Spatial, Temporal and MultiDimensional Data Modelling and Analysis“, Quebec, Canada, Oct 2003.
4. De la Losa, A.; Cervelle, B. 3D Topological modeling and visualization for 3D GIS. Computers \& Graphics, No 23, 1999, p. 469-478.

5. Lemmen, C.; Van Oosterom, P. 3D Cadastres. Computers, Environment and Urban Systems, Vol 27, 2003. 337-343 p.

6. Billen, R.; Zlatanova, S. 3D spatial relationships model: a useful concept for 3D cadastre? Computers, Environment and Urban Systems, Vol 27, 2003, p. 411-425.

7. Egenhofer, M. J.; Frank, A. U.; Jackson, J. P. A topological data model for spatial databases. National Center for Geographic Information and Analysis, Technical report, No 104, 1989. 1-17 p.

8. Egenhofer, M. J.; Herring, J. R. A mathematical framework for the definition of topological relationships. In: Proceedings of Fourth International Symposium on SDH. Zurich, Switzerland, 1990. p. 803-813.

9. Zlatanova, S. 3D GIS for Urban development. PhD thesis, ITC. The Netherlands, 2000. 222 p.

Kęstutis ČYPAS. Doctoral student. Vilnius Gediminas Technical University, Dept of Geodesy and Cadastre, Saulètekio al. 11, LT-10223 Vilnius-40, Lithuania (Ph +37052744703), e-mail: kestutis.cypas@ap.vtu.lt.

A graduate of Vilnius Gediminas Technical University (VGTU) (MSc, 2001). Post graduate studies at Gjoevik University College in 1998. Author of 3 publications.

Research interests: geoinformation systems, 3D modelling. 